\title{
Purification, Properties, and Diagnosis of Banana Bract Mosaic Potyvirus and Its Distinction from Abaca Mosaic Potyvirus
}

\author{
J. E. Thomas, A. D. W. Geering, C. F. Gambley, A. F. Kessling, and M. White
}

Plant Protection Unit, Department of Primary Industries, 80 Meiers Road, Indooroopilly, Queensland, 4068, Australia. Accepted for publication 20 March 1997.

\section{ABSTRACT}

Thomas, J. E., Geering, A. D. W., Gambley, C. F., Kessling, A. F., and White, M. 1997. Purification, properties, and diagnosis of banana bract mosaic potyvirus and its distinction from abaca mosaic potyvirus. Phytopathology 87:698-705.

Using biochemical, serological, and cytopathological evidence, we have confirmed that banana bract mosaic virus (BBrMV) is a distinct member of the family Potyviridae. Virions of a Philippine isolate of BBrMV were purified from field-infected banana cv. Cardaba. Particles were approximately $725-\mathrm{nm}$ long, banded at a density equivalent to 1.29 to $1.31 \mathrm{~g} / \mathrm{ml}$ in cesium chloride equilibrium gradients, and had an $A_{260 / 280}$ of 1.17 . Yields of about $4 \mathrm{mg} / \mathrm{kg}$ were obtained from fresh or frozen leaf midrib or lamina tissue. Three major protein species with sizes of 31, 37, and $39 \mathrm{kDa}$ were resolved from dissociated virions, and all reacted specifically with polyclonal antibodies to BBrMV. Infected leaf cells contained typical pinwheel inclusions. Virus-specific cDNA was amplified from field samples by reverse transcription-polymerase chain reaction (RT-PCR) assay using potyvirus degenerate primers. In plate-trapped antigen-enzyme-linked immunosorbent assay (ELISA), weak serological relationships were demonstrated between BBrMV and other members of the family Potyviridae, including abaca mosaic (AbaMV), dasheen mosaic, maize dwarf mosaic, sorghum mosaic, sugarcane mosaic, and wheat streak mosaic viruses. Despite similarities in the symptoms caused by the two viruses, AbaMV was serologically distinct from BBrMV and reacted only weakly, or not at all, with BBrMV antibodies in double-antibody sandwich (DAS)-ELISA. No cross reactions were observed when RTPCR products from the two viruses were examined by Southern blot hybridization using BBrMV- and AbaMV-specific digoxigenin-labeled DNA probes. BBrMV was consistently associated with banana bract mosaic disease, as assessed by DAS-ELISA and Southern blot hybridization using DNA probes. The known geographical distribution of BBrMV was extended to include India (Kokkan disease) and Sri Lanka.
Banana (Musa spp.) is a vegetatively propagated crop grown both as a staple food and as a major cash crop for local and export markets throughout the tropical and subtropical areas of the world. Three viruses that infect banana have been characterized: banana bunchy top virus (BBTV) $(4,27)$, banana streak badnavirus (BSV) (17), and cucumber mosaic cucumovirus (CMV) (26). A fourth virus-like disease, banana bract mosaic, was first noted in the Philippines in 1979 (18) and, subsequently, yield losses of up to $40 \%$ have been recorded (23). The characteristic mosaic symptoms on the flower bracts give the disease its common name. The virus has characteristics typical of a potyvirus. The causal agent is transmitted in the nonpersistent manner by several species of aphids (18). Although efficient purification methods have not been reported, partially purified extracts have been obtained and contain flexuous virus-like particles approximately $750 \times 11 \mathrm{~nm}(20)$. The C-terminal half of the coat protein and the 3 '-untranslated region of a Philippine isolate of banana bract mosaic virus (BBrMV) have recently been cloned and sequenced, demonstrating it to be a distinct potyvirus (3). The putative coat protein also reacted in immunoblots with polyclonal potyvirus group-specific antibodies (3). No alternative hosts of BBrMV outside Musa are known, and the virus has not been transmitted by mechanical inoculation. Banana plants with similar symptoms and also containing flexuous rod-shaped particles have been observed in India, where the disorder is known locally as Kokkan disease (2).

Corresponding author: J. E. Thomas; E-mail address: thomasje@dpi.qld.gov.au

The amino acid sequence data reported in this paper were derived from nucleotide sequence data that have been deposited with GenBank under accession numbers U88882 (clone p509-5), U88885 (p509-42), and U88887 (p509-90).

Publication no. P-1997-0505-01R

(C) 1997 The American Phytopathological Society
In the Philippines, Musa textilis (abaca or Manila hemp) can be infected by abaca mosaic virus (AbaMV), considered to be a strain of sugarcane mosaic potyvirus (9). AbaMV can also be transmitted to edible Musa spp., causing somewhat similar symptoms to banana bract mosaic disease (26), raising the question as to whether the two diseases are caused by the same virus.

This paper describes the purification and some properties of BBrMV, its detection by serological and reverse transcriptionpolymerase chain reaction (RT-PCR) assays, its consistent association with banana bract mosaic disease, and confirms its classification as a potyvirus. The relationship between AbaMV and $\mathrm{BBrMV}$ is also examined.

\section{MATERIALS AND METHODS}

Virus isolates. Field samples of banana and abaca with typical symptoms of either banana bract mosaic or abaca mosaic disease were collected in the Philippines, India, and Sri Lanka (Table 1) and imported into Australia under Australian Quarantine and Inspection Service license. Quarantine restrictions prevented propagation of the viruses in Australia. Tissue was either used fresh or frozen at $-70^{\circ} \mathrm{C}$. BBrMV isolate 509 was used for antiserum production and for cloning, sequencing, and probe production. This isolate was obtained from a single plant of cv. Cardaba (ABB/BBB) from Davao, Philippines, and, when indexed, was shown to be free of other detectable viruses including AbaMV (cDNA probe), BBTV, BSV, and CMV (8). Healthy controls were glasshouse-grown plants of Cavendish cv. Williams (AAA) from Queensland and were free of all detectable viruses, as determined by the tests noted above and electron microscopy of sap extracts.

As positive controls in enzyme-linked immunosorbent assays (ELISA), freeze-dried leaf tissues containing the following potyvirus and rymovirus isolates were used (acronyms by Hull et al. [13]; supplier or Department of Primary Industries reference col- 
lection number in parentheses): dasheen mosaic virus (DsMV, isolate 455), johnsongrass mosaic virus (JGMV, isolate 340), sugarcane mosaic virus (SCMV, isolate 366), maize dwarf mosaic virus (MDMV, strain A; R. E. Ford), sorghum mosaic virus (SrMV, strain SCMV-H; R. E. Ford), and wheat streak mosaic virus (WSMV; W. G. Langenberg). As a positive control in RTPCR, fresh tissue of JGMV isolate 535 was used.

Isolates of other banana viruses were also used for serological comparisons: BBTV (isolate 482), BSV (isolate 517), and CMV (isolate 207).

Electron microscopy. Virion preparations were placed on collodion-coated, carbon-stabilized copper grids, negatively stained with $2 \%(\mathrm{wt} / \mathrm{vol})$ ammonium molybdate $(\mathrm{pH} 5.8)$ or $2 \%(\mathrm{wt} / \mathrm{vol})$ potassium phosphotungstate $(\mathrm{pH} 7.0)$, and viewed in an electron microscope. Tobacco mosaic tobamovirus was used as an internal size standard, and the virions were assumed to be 18 -nm wide $\times$ 300-nm long (31). Tissue was processed for thin section electron microscopy essentially as described by Greber and Gowanlock (10).

Virion purification. All procedures were carried out at $5^{\circ} \mathrm{C}$, unless otherwise specified. Relative centrifugal force in the ultracentrifuge was calculated at $R_{a v}$.

Leaf lamina or midrib tissue of BBrMV-509-infected banana was used fresh or after storage at $-70^{\circ} \mathrm{C}$ for up to 12 weeks. The tissue was diced, frozen in liquid nitrogen immediately, and then finely powdered in a Waring blender (Waring, New Hartford, CT) with a metal bowl. The powdered, frozen tissue was thawed in 5 volumes of extraction buffer (EB; $0.5 \mathrm{M}$ borate [pH 6.8] and $0.2 \%$ [vol/vol] 2-mercaptoethanol). The slurry was then strained through four layers of cheesecloth, and the filtrate was clarified by centrifugation at $10,000 \times g$ for $10 \mathrm{~min}$. Triton X-100 was then added to a final concentration of $2.5 \%(\mathrm{vol} / \mathrm{vol})$ and the mixture stirred for 1 to $1.5 \mathrm{~h}$. The mixture was centrifuged for $2 \mathrm{~h}$ at $40,000 \mathrm{rpm}(125,000 \times \mathrm{g})$ through a $15-\mathrm{ml}$ cushion of $30 \%(\mathrm{wt} / \mathrm{vol})$ sucrose in EB, using Beckman Quickseal tubes in a Type $45 \mathrm{Ti}$ rotor (Beckman Instruments, Inc., Palo Alto, CA). Pellets were resuspended in $0.25 \mathrm{M}$ borate buffer, $\mathrm{pH} 6.8$ (1 ml per tube), using a Dounce homogenizer, and then stirred for several hours. The virus particles were further purified by equilibrium centrifugation in cesium chloride $(0.44 \mathrm{~g} / \mathrm{ml})$ at $10^{\circ} \mathrm{C}$ for $16 \mathrm{~h}$ at $32,000 \mathrm{rpm}$ $(126,000 \times g$, Beckman SW 41 Ti rotor [Beckman Instruments, Inc.]) or 38,000 rpm $(137,000 \times g$, Beckman SW 55 Ti rotor [Beckman Instruments, Inc.]). Gradients were fractionated using an Isco fractionator (Isco, Inc., Lincoln, NE) with Fluorinert chase solution (Isco, Inc.). UV-absorbing, virion-containing fractions were diluted with buffer, concentrated by ultracentrifugation for $1 \mathrm{~h}$ at $40,000 \mathrm{rpm}(118,000 \times g)$ in a Beckman Type 70 Ti rotor (Beckman Instruments, Inc.), and the resulting pellets resuspended in a small volume of $0.05 \mathrm{M}$ borate buffer, $\mathrm{pH} 6.8$, or $0.05 \mathrm{M}$ sodium phosphate buffer, $\mathrm{pH}$ 7.0.

The concentration of purified virion preparations was estimated by UV spectrophotometry, using an extinction coefficient of 2.4 $\mathrm{mg} / \mathrm{ml} / \mathrm{cm}$, as determined for tobacco etch potyvirus (22).

Serology. A rabbit polyclonal antiserum to BBrMV-509 was prepared using a series of three intramuscular injections of purified virions. The first injection on day 0 contained $140 \mu \mathrm{g}$ of

TABLE 1. Abaca mosaic virus (AbaMV) and banana bract mosaic virus (BBrMV) isolates used in this experimental work

\begin{tabular}{|c|c|c|c|c|c|}
\hline Virus & Origin & Cultivar/genotype & Isolate no. & Sample type $(\mathrm{F} / \mathrm{A})^{\mathrm{a}}$ & Additional viruses detected \\
\hline \multirow[t]{31}{*}{ BBrMV } & India & & & & \\
\hline & Bangalore & Nendran/AAB & 513 & $\mathrm{~F}$ & \\
\hline & Kannara & Poovan (syn. Mysore)/AAB & 556 & $\mathrm{~F}$ & $\mathrm{BSV}^{\mathrm{b}}$ \\
\hline & Kannara & Chinia/AAB & 557 & $\mathrm{~F}$ & \\
\hline & Kannara & Enikomban (syn. Nendran)/AAB & 559 & $\mathrm{~F}$ & \\
\hline & Kannara & Ney Poovan/AB & 560 & $\mathrm{~F}$ & \\
\hline & Trichur & Nendran & 561 & $\mathrm{~F}$ & \\
\hline & Philippines & & & & \\
\hline & Los Baños & Unknown & 353 & $\mathrm{~F}$ & \\
\hline & Davao & Cardaba/ABB/BBB & 509 & $\mathrm{~F}$ & \\
\hline & Los Baños & Abaca (Musa textilis) & 510 & A & \\
\hline & Davao & Cardaba & 511 & $\mathrm{~F}$ & \\
\hline & Los Baños & Unknown & 512 & $\mathrm{~F}$ & \\
\hline & Davao & Cardaba & $514-2$ & $\mathrm{~F}$ & \\
\hline & Davao & Cardaba & $514-3$ & $\mathrm{~F}$ & \\
\hline & Davao & Cardaba & $514-4$ & $\mathrm{~F}$ & \\
\hline & Davao & Mysore/AAB & $514-8$ & $\mathrm{~F}$ & BSV \\
\hline & Davao & Mysore & $514-9$ & $\mathrm{~F}$ & BSV \\
\hline & Davao & Kalapua/ABB & 514-10 & $\mathrm{F}$ & BSV \\
\hline & Davao & Kalapua & 514-11 & $\mathrm{F}$ & BSV \\
\hline & Mindanao & Grand Naine/AAA & $515-5$ & A & \\
\hline & Mindanao & Butuhan/BB & $515-6$ & A & \\
\hline & Mindanao & Grand Naine & $515-7$ & $\mathrm{~A}$ & \\
\hline & Laguilayan & Lakatan/AA & $515-9$ & $\mathrm{~F}$ & \\
\hline & Los Baños & Unknown & 516 & $\mathrm{~F}$ & \\
\hline & Los Baños & Tangong/AA/AAA & 533 & $\mathrm{~F}$ & \\
\hline & Sri Lanka & & & & \\
\hline & Wagolla & Embul (syn. Mysore)/AAB & 552 & $\mathrm{~F}$ & BSV \\
\hline & Wagolla & Embul & 553 & $\mathrm{~F}$ & $\mathrm{BBTV}^{\mathrm{c}}$ \\
\hline & Wagolla & Embul & 554 & $\mathrm{~F}$ & \\
\hline & Ganaruwa & Embul & 555 & $\mathrm{~F}$ & BSV \\
\hline \multirow[t]{7}{*}{ AbaMV } & Philippines & & & & \\
\hline & Mindanao & Grand Naine & $515-1$ & A & \\
\hline & Mindanao & Abaca & $515-2$ & A & \\
\hline & Baganihan & Abaca & $515-3$ & $\mathrm{~F}$ & \\
\hline & Mindanao & Grand Naine & $515-4$ & A & \\
\hline & Mindanao & Grand Naine & $515-16$ & A & \\
\hline & Los Baños & Unknown & 543 & Unknown & \\
\hline
\end{tabular}

\footnotetext{
a Virus isolates are either experimentally aphid-inoculated (A; supplied by L. Magnaye and L. Heradura, Philippines) or field samples (F).

b Banana streak badnavirus.

c Banana bunchy top virus.
} 
BBrMV in an equal volume of Freund's complete adjuvant. The second and third injections on days $28(110 \mu \mathrm{g})$ and $49(200 \mu \mathrm{g})$ contained an equal volume of Freund's incomplete adjuvant. Blood was collected on days $35,42,56$, and 62 , and serum from the bleed on day 56 was used unless otherwise specified. Immunoglobulin $G$ (IgG) was prepared from the serum by ammonium sulfate precipitation followed by ion-exchange chromatography and was subsequently used to make alkaline phosphatase conjugates (5).

Antisera to the following members of the family Potyviridae were also used (suppliers in parentheses): DsMV (D. E. Purcifull); WSMV (W. G. Langenberg); MDMV, strain MDMV-A (R. Toler); SCMV, strain SCMV-D (R. Toler); JGMV, strain SCMV-JG (D. D. Shukla); SrMV, strain SCMV-I (R. Toler); and potyvirus group monoclonal antibody (Agdia, Elkhart, IN).

Serological relationships were investigated by plate-trapped antigen (PTA)-ELISA (19) or double-antibody sandwich (DAS)-ELISA (5). Polystyrene plates (Immulon 3 or 4; Dynatech Laboratories, Inc., Alexandria, VA; or Maxisorb; Nunc, Roskilde, Denmark) were used, and reaction volumes were $100 \mu \mathrm{l}$ per well.

For PTA-ELISA, plant tissue was macerated in $0.05 \mathrm{M}$ carbonate buffer, $\mathrm{pH} 9.6$, containing $10 \mathrm{mM}$ sodium diethyldithiocarbamate $(1 \mathrm{~g}$ of fresh tissue or $0.1 \mathrm{~g}$ of freeze-dried tissue $/ 50 \mathrm{ml}$ of buffer) and briefly centrifuged before addition to the ELISA plate. Polyclonal detecting antibodies in crude serum were used diluted $1: 1,000$ to $1: 5,000$ in an extract of healthy plant sap ( $1 \mathrm{~g}$ of leaf/30 $\mathrm{ml}$ of phosphate-buffered saline (PBS)-Tween (0.1 M sodium phosphate [pH 7.4], $0.14 \mathrm{M}$ sodium chloride, and $0.05 \%$ [ $\mathrm{vol} / \mathrm{vol}]$ Tween-20). Monoclonal antibodies were diluted to their optimal concentration in PBS-Tween alone. Bound polyclonal or monoclonal antibodies were, in turn, detected with goat anti-rabbit (A3687 [Sigma Chemical Co., St. Louis] diluted 1:30,000 in PBSTween) and sheep anti-mouse (DAP [Silenus, Melbourne, Australia] diluted 1:2,000 in PBS-Tween) alkaline phosphatase conjugates, respectively. Sap extract, antibody, and conjugate incubations were for 2 to $3 \mathrm{~h}$ at room temperature or overnight at $5^{\circ} \mathrm{C}$.

For DAS-ELISA, plates were coated with $\operatorname{IgG}(3 \mu \mathrm{g} / \mathrm{ml})$ for 2 to $3 \mathrm{~h}$ at room temperature. Plant tissue was macerated in $0.2 \mathrm{M}$ potassium phosphate, $\mathrm{pH} 7.0$, containing $15 \mathrm{mM}$ EDTA, $2 \%$ (wt/vol) polyvinyl pyrrolidone, $2 \%(\mathrm{wt} / \mathrm{vol})$ polyethylene glycol 6,000 , and $0.4 \%$ (wt/vol) sodium sulfite ( $1 \mathrm{~g}$ of tissue/10 $\mathrm{ml}$ of buffer; B. E. L.

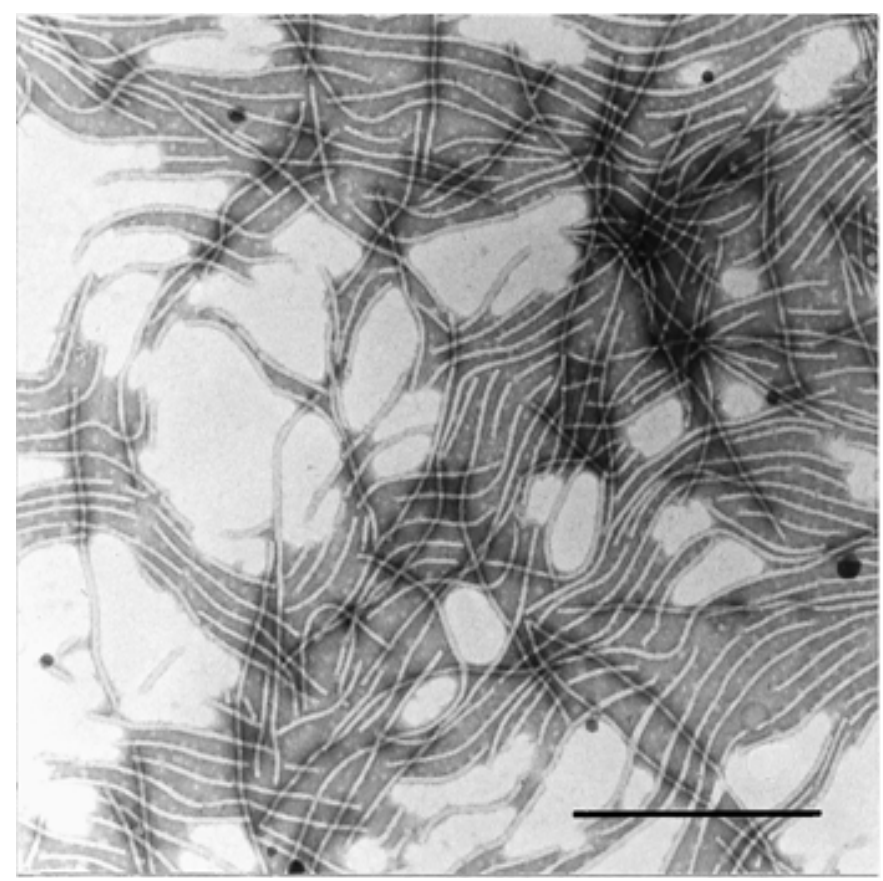

Fig. 1. Purified virions of banana bract mosaic virus negatively stained with $2 \%$ potassium phosphotungstate. Bar represents $400 \mathrm{~nm}$.
Lockhart, personal communication) and briefly centrifuged before addition to the plate and incubation overnight at $5^{\circ} \mathrm{C}$. An antiBBrMV IgG alkaline phosphatase conjugate, diluted 1:500 in PBS-Tween, was next added and incubated for 3 to $4 \mathrm{~h}$ at room temperature. For both forms of ELISA, hydrolysis of the substrate $p$-nitrophenyl phosphate $(1 \mathrm{mg} / \mathrm{ml})$ was monitored at $A_{410}$ with a Dynatech MR7000 ELISA plate reader (Dynatech Laboratories, Inc.). Samples were considered positive when the mean absorbance of duplicate wells exceeded twice the mean absorbance of appropriate healthy controls.

The sensitivity of the DAS-ELISA was determined using a dilution series of purified BBrMV-509 in a 1:10 diluted extract of healthy banana. Antibody titer was assessed by PTA-ELISA and defined as the maximum dilution giving a positive reaction and an $A_{410}>0.1$ after $90 \mathrm{~min}$ of substrate incubation.

Gel electrophoresis and immunoblotting. Virions of BBrMV509 were dissociated by boiling for $2 \mathrm{~min}$ in $62.5 \mathrm{mM}$ Tris- $\mathrm{HCl}$, $\mathrm{pH}$ 6.8, containing 3\% (wt/vol) sodium dodecyl sulfate (SDS), 5\% (vol/vol) 2-mercaptoethanol, 10\% (vol/vol) glycerol, and $0.01 \%$ ( $\mathrm{vol} / \mathrm{vol}$ ) bromophenol blue. Proteins were then separated by SDSpolyacrylamide gel electrophoresis (PAGE) (15) and visualized by staining with Coomassie blue (24). Size estimates were made by comparison with Bio-Rad low range protein molecular weight markers (Bio-Rad Laboratories, Hercules, CA). Separated proteins were electrophoretically transferred to $0.45-\mu \mathrm{m}$ nitrocellulose membrane (Bio-Rad Laboratories) using a Bio-Rad mini trans-blot cell (Bio-Rad Laboratories) according to the manufacturer's instructions. Protein transfer was monitored and size estimates determined with prestained molecular weight markers (Rainbow markers; Amersham International plc, Little Chalfront, United Kingdom). After transfer, the membrane was air-dried, rinsed with $10 \mathrm{mM}$ Tris- $\mathrm{HCl}(\mathrm{pH} 7.4)$ containing $150 \mathrm{mM} \mathrm{NaCl}$ and $1 \mathrm{mM}$ EDTA (rinse buffer, RB), and then blocked by incubation in $100 \mathrm{ml}$ of RB containing 5\% (wt/vol) skim milk powder for 60 to $90 \mathrm{~min}$ at room temperature. Proteins were reacted with anti-BBrMV polyclonal $\operatorname{IgG}(5 \mu \mathrm{g} / \mathrm{ml})$ prepared in RB containing $0.1 \%$ Triton X-100 (RBT) and an extract of healthy banana sap $(1 \mathrm{~g} / 100 \mathrm{ml}$ of RBT). Bound antibodies were detected with goat anti-rabbit IgG-alkaline phosphatase conjugate (A3687) diluted 1:30,000 in RBT. Both detecting antibody and conjugate solutions were used at the rate of 0.125 $\mathrm{ml} / \mathrm{cm}^{2}$ of membrane and were each agitated with the membrane for $60 \mathrm{~min}$ at room temperature in sealed plastic bags. After each incubation, the membranes were washed five times, $5 \mathrm{~min}$ each, by vigorous agitation with about $100 \mathrm{ml}$ of RBT. Bound conjugate was detected with the substrates BCIP/NBT (Bio-Rad Laboratories) used according to the manufacturer's instructions.

Nucleic acid extraction and RT-PCR. Two methods were used to prepare RNA template for RT-PCR.

Total nucleic acid extract (TNAE). Total nucleic acids were extracted from plant tissue using a method modified from Pearson et al. (21). Frozen tissue samples were ground with a chilled mortar and pestle at the rate of $1 \mathrm{~g}$ per 1 to $2 \mathrm{ml}$ of $50 \mathrm{mM}$ Tris- $\mathrm{HCl}(\mathrm{pH}$ 7.2) containing $100 \mathrm{mM}$ sodium acetate, $10 \mathrm{mM}$ EDTA, and $0.1 \%$ ( vol/vol) monothioglycerol. The extract was centrifuged for $2 \mathrm{~min}$ at $12,000 \times g\left(5^{\circ} \mathrm{C}\right)$, and, to $300 \mu \mathrm{l}$ of supernatant, there was added $30 \mu \mathrm{l}$ of $10 \%$ (wt/vol) SDS and $600 \mu \mathrm{l}$ of phenol/chloroform/isoamyl alcohol (25:24:1). The mixture was vortexed for $1 \mathrm{~min}$, centrifuged $\left(5 \mathrm{~min}\right.$ at $12,000 \times g$ at $\left.5^{\circ} \mathrm{C}\right)$, and the supernatant reextracted with another $600 \mu \mathrm{l}$ of phenol/chloroform/isoamyl alcohol. To the final aqueous phase was added 0.05 volume of $3 \mathrm{M}$ sodium acetate, $\mathrm{pH} 5.5$, and 2.5 volumes of ice-cold ethanol. The extract was stored at $-70^{\circ} \mathrm{C}$ for $2 \mathrm{~h}$ and then centrifuged, and the pellet was washed with $70 \%$ ethanol. The final pellet was dried in vacuo, and then resuspended in $20 \mu \mathrm{l}$ of TE buffer (10 mM Tris- $\mathrm{HCl}, \mathrm{pH} 8.0$, and 1 mM EDTA) or sterile distilled water including $10 \mathrm{mM}$ dithiothreitol (DTT) and 40 units of RNasin (Progen, Brisbane, Australia).

"Leaf soak" extract. Extracts were made essentially as described by Thomson and Dietzgen (29). Frozen tissue samples (1 to $2 \mathrm{~mm}^{3}$ ) 
were crushed in $30 \mu$ of $100 \mathrm{mM}$ Tris- $\mathrm{HCl}, \mathrm{pH} 8.4$, containing 1.0 $\mathrm{M} \mathrm{KCl}$ and $10 \mathrm{mM}$ EDTA, and heated at $95^{\circ} \mathrm{C}$ for 5 to $10 \mathrm{~min}$.

Reverse transcription and PCR were either done separately or combined in a single tube. In the former method, TNAE $(0.2 \mu \mathrm{l})$ was diluted to $8 \mu \mathrm{l}$ in diethylpyrocarbonate (DEPC)-treated water, heated to $65^{\circ} \mathrm{C}$ for $10 \mathrm{~min}$, and then immediately placed on ice. Tube contents were collected by brief centrifugation, and then $5 \mu \mathrm{l}$ of bulk first-strand cDNA reaction mix including Moloney murine leukemia virus reverse transcriptase (Pharmacia Biotechnology Inc., Uppsala, Sweden), $1 \mu \mathrm{l}$ of DTT solution (200 pmoles), and $1 \mu \mathrm{l}$ (20 pmoles) of downstream primer D341 (16) were added and incubated at $37^{\circ} \mathrm{C}$ for $1 \mathrm{~h}$.

Degenerate primers from the core of the coat protein were used in PCR (16). Reaction volumes of $25 \mu \mathrm{l}$ contained $2 \mu \mathrm{l}$ of firststrand cDNA, 5 pmoles each of primers U341 and D341, 2 units of Taq polymerase (Gibco BRL, Life Technologies, Gaithersburg, MD), 25 nmoles of each deoxynucleoside triphosphate, $1.5 \mathrm{mM}$ $\mathrm{MgCl}_{2}$, and $2.5 \mu \mathrm{l}$ of $10 \times$ PCR buffer $(1 \times=20 \mathrm{mM}$ Tris- $\mathrm{HCl}, \mathrm{pH}$ 8.4, and $50 \mathrm{mM} \mathrm{KCl}$; Gibco BRL, Life Technologies). Tubes were made up to volume with reverse osmosis (RO) water and overlaid with $20 \mu \mathrm{l}$ of mineral oil. Thirty-three reaction cycles were performed, with periods of $94^{\circ} \mathrm{C} / 30 \mathrm{~s}, 56^{\circ} \mathrm{C} / 3 \mathrm{~min}$, and $72^{\circ} \mathrm{C} / 1 \mathrm{~min}$ (6). All amplifications were carried out in a Hybaid Omnigene thermal cycler (Hybaid, Ltd., Teddington, Middlesex, United Kingdom), and $8 \mu \mathrm{l}$ of product was analyzed by electrophoresis on agarose gels in $0.5 \times$ or $1 \times$ Tris-borate-EDTA (TBE), followed by staining with ethidium bromide (24).

For the single-tube RT-PCR, RNA template was either $2 \mu \mathrm{l}$ of "leaf soak" extract diluted 1:10 in RO water, or $2 \mu \mathrm{l}$ of undiluted TNAE. The RT-PCR mixture and cycling parameters were as described for PCR, except that, for RT-PCR, the mixture also contained 20 units of reverse transcriptase (Superscript I; Gibco BRL, Life Technologies), and prior to commencing the PCR cycling parameters, there was a 60 -min incubation at $37^{\circ} \mathrm{C}$, followed by a 90-s denaturation step at $94^{\circ} \mathrm{C}$.

The detection limit of the single-tube RT-PCR using a "leaf soak" extract was examined using template dilutions of 1:10 through 1:3,200.

Cloning and sequencing of RT-PCR products. RT-PCR products were cloned using the pCRScript $\mathrm{SK}(+)$ cloning kit (Stratagene Inc., La Jolla, CA) according to the manufacturer's instructions. Suspected viral inserts were selected by insert size and confirmed by cycle sequencing using T3 and T7 primers in an Applied Biosystems 373A automated sequencer (Applied Biosystems, Inc., Foster City, CA). The sequences were translated and aligned using the GCG software package (7) and the ClustalW program (28), respectively, both available through the Australian National Genome Information Service at the University of Sydney.

Southern blot hybridizations. Procedures were essentially as described by Sambrook et al. (24). For Southern blot analysis, RTPCR products were electrophoresed on $0.8 \%$ agarose gels in $1 \times$ TBE and capillary blotted to Hybond-N nylon membranes (Amersham International plc). Digoxigenin-labeled probes of $341 \mathrm{bp}$ were prepared from cloned inserts of BBrMV-509 and AbaMV-543 using a PCR-labeling kit (Boehringer Mannheim, Mannheim, Germany). Prehybridizations, hybridizations, and stripping of the blots were done essentially according to the manufacturer's instructions, and a chemiluminescent detection system (Lumigen; Boehringer Mannheim) was used. Hybridizations were at $45^{\circ} \mathrm{C}$ overnight in Easy Hyb buffer (Boehringer Mannheim). Washes were done at high stringency $\left(0.1 \times \mathrm{SSC} / 65^{\circ} \mathrm{C} ; 1 \times \mathrm{SSC}\right.$ is $0.15 \mathrm{M} \mathrm{NaCl}$ plus $0.015 \mathrm{M}$ sodium citrate) or at moderate stringency $\left(2 \times \mathrm{SSC} / 65^{\circ} \mathrm{C}\right)(12)$.

\section{RESULTS}

Virion purification. In preliminary experiments, a number of potyvirus purification methods were tried $(11,20,30)$, though none resulted in a high yield of relatively pure virions. With the purifi- cation method developed in this study, purified virion preparations that were essentially free of host contaminants were obtained, as assessed by electron microscopy and SDS-PAGE. The particles were not aggregated (Fig. 1), had an $A_{260 / 280}$ of approximately 1.17 (uncorrected for light scattering), and banded in a zone in cesium chloride gradients equivalent to a density of 1.29 to $1.31 \mathrm{~g} \mathrm{~cm}^{-3}$. Yields were in the order of $4 \mathrm{mg} / \mathrm{kg}$ of tissue, and the virus was successfully recovered from lamina or midrib tissue from fresh or frozen material.

Electron microscopy. Particles from a purified preparation had a mean length of $725 \mathrm{~nm}$ (25 particles measured). BBrMV-infected cells contained pinwheel inclusions and scrolls typical of those associated with infection by a potyvirus (Fig. 2).

BBrMV protein. Three major protein bands with estimated sizes of 31,37 , and $39 \mathrm{kDa}$ (mean of four determinations) were visible on Coomassie-stained SDS-polyacrylamide gels of dissociated BBrMV (Fig. 3A, lane 2). These bands were absent from corresponding healthy preparations (Fig. 3A, lane 3). All three bands reacted specifically in immunoblots with anti-BBrMV polyclonal antibodies that had been cross-absorbed with healthy banana sap (Fig. 3B, lane 1) and were present when preparations were dissociated fresh or after storage at $-20^{\circ} \mathrm{C}$ for several weeks. No antigen was detected in immunoblots from corresponding healthy banana preparations (Fig. 3B, lane 2).

Serology. Serum collected from all four bleeds had a virus-specific titer in PTA-ELISA of $10^{-5}$.

BBrMV was detected in tissue extracts from field-infected banana by both PTA- and DAS-ELISA. In PTA-ELISA, cross-absorption of the detecting antibodies with a tissue extract from healthy bananas was essential. For example, after 35 min of substrate incubation, the $A_{410}$ values for a healthy and a diseased extract were 0.04 and 0.32 , respectively, when the detecting antibody was cross-absorbed, but 0.12 and 0.38 when not cross-absorbed. All 16 banana bract mosaic disease samples tested from the Philippines, the four samples from Sri Lanka, and the six samples from India reacted positively in DAS-ELISA with the BBrMV antibodies. No reaction was obtained from plants infected with BBTV, CMV, or BSV alone. In a typical DAS-ELISA, after 80 min of substrate incubation, the $A_{410}$ value for a healthy banana sample was 0.01 and, for four infected samples, were 1.16, 0.30, 0.70 (Philippines bract mosaic disease, isolates 509, 511, and 515-5,

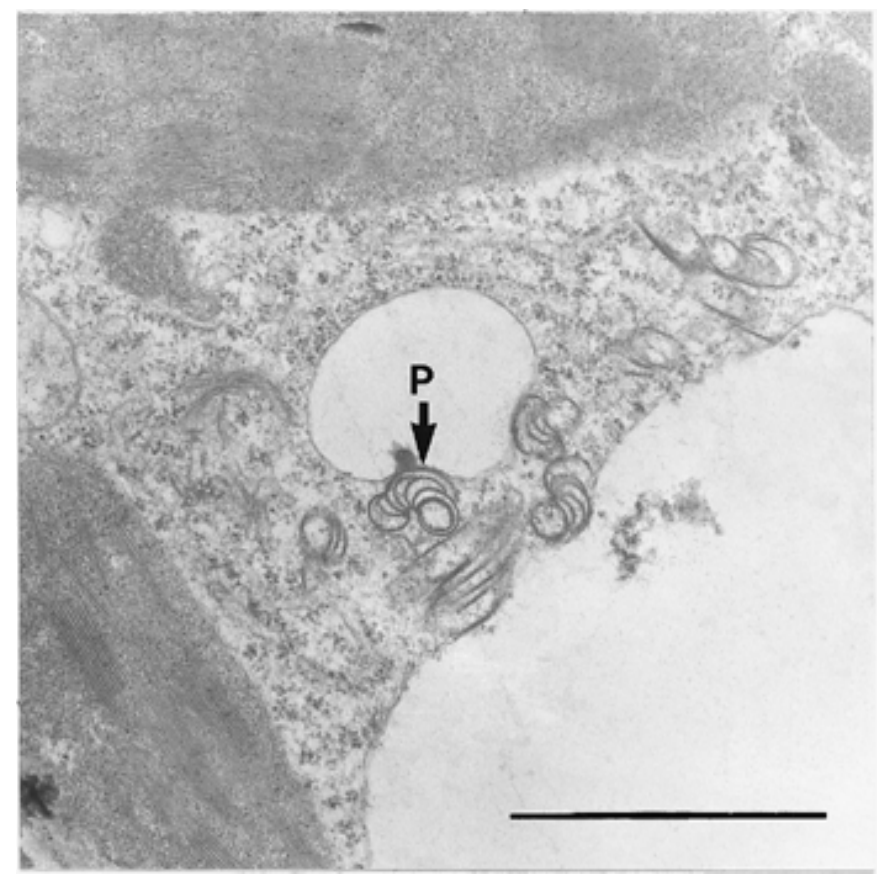

Fig. 2. Pinwheel inclusions $(\mathrm{P})$ in a banana bract mosaic virus-infected cell. Bar represents $1 \mu \mathrm{m}$. 
respectively), and 0.26 (Indian Kokkan disease, isolate 513). In a second test, healthy samples averaged 0.02 , and five infected samples were 0.80 (BBrMV-509), 0.36, 0.57, 0.80, and 0.10 (Sri Lankan samples). For DAS-ELISA, the dilution endpoint of detection of purified BBrMV, prepared in a 1:10 extract of healthy banana sap, was $16 \mathrm{ng} / \mathrm{ml}$.

Serological relationships between BBrMV, AbaMV, and other potyviruses. Positive reactions were obtained in PTA-ELISA between the Agdia potyvirus group monoclonal antibody (Agdia, Inc.) and five of 10 Philippines field isolates of BBrMV. In one test, healthy control samples gave an $A_{410}$ of 0.1 , negative test samples (isolates 515-5, 515-7, and two Philippine field samples) were 0.04 to 0.08 and positive samples were $0.29,0.33,0.36$, and 0.68 (isolates 533, 512, 516, and 515-6, respectively). In a second test, $A_{410}$ values for a healthy control and a BBrMV-509 test sample were 0.02 and 0.07 , respectively.

Two isolates each of BBrMV (509 and 516) and AbaMV (515-3 and 543) were tested in PTA-ELISA against a range of potyvirus and rymovirus antisera (Table 2). Weak serological reactions were detected between BBrMV isolates and antisera to SCMV, MDMV, SrMV, DsMV, and WSMV. In reciprocal tests, JGMV, MDMV, SCMV, and SrMV did not react with antiserum to BBrMV (data not shown). Weak serological reactions were detected between AbaMV and antisera to BBrMV and JGMV, while moderate reactions occurred with antisera to SCMV, MDMV, SrMV, and DsMV. In all these tests, strong positive reactions, usually at least $10 \times$ the healthy control, were obtained for all homologous virus/antibody combinations.

Three isolates of suspected AbaMV (515-1, 515-2, and 515-3) did not react $\left(A_{410} 0.01\right)$ and one $(515-4)$ reacted only weakly $\left(A_{410}\right.$ $0.074)$ in DAS-ELISA using antibodies to BBrMV. A fifth isolate (510, originally supplied as AbaMV) reacted strongly $\left(A_{410} 0.97\right)$. In the same test, healthy banana sap gave an $A_{410}$ of 0.01 and seven BBrMV-infected samples were in the range $A_{410} 0.65$ to 1.52. AbaMV samples 515-1 and 515-2 were shown to contain flexuous, rod-shaped particles by electron microscopy, and all samples gave positive PTA-ELISA reactions against antibodies to other potyviruses (data not shown) and an amplification product of the expected size in RT-PCR. Thus, the negative ELISA reac-

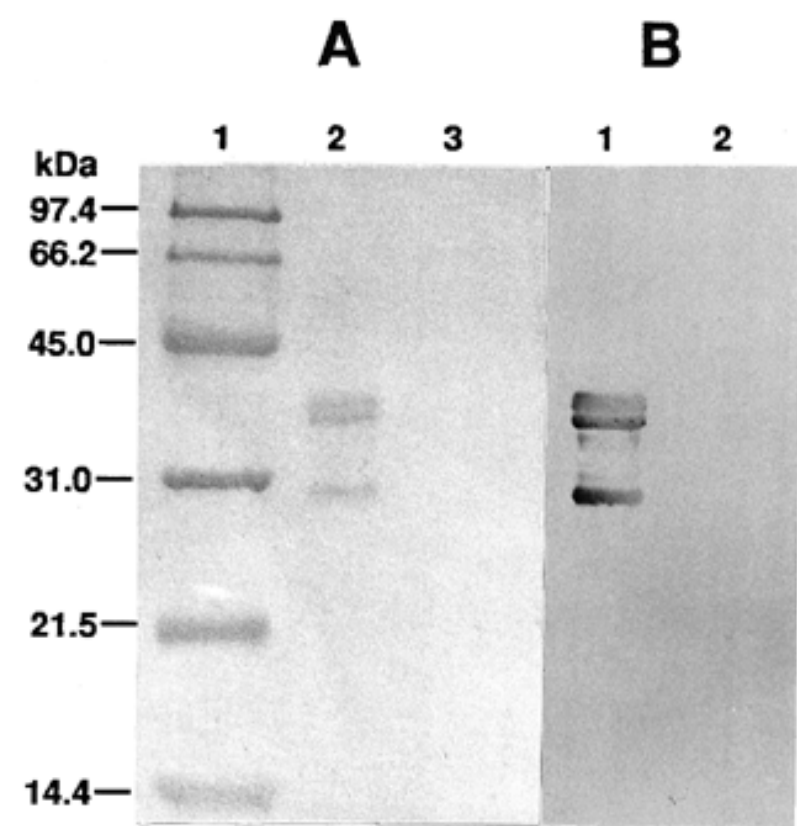

Fig. 3. Sodium dodecyl sulfate-polyacrylamide gel electrophoresis (SDSPAGE) and immunoblot analyses of banana bract mosaic virus (BBrMV) proteins. A, SDS-PAGE: lane 1, molecular weight markers; lane 2, purified BBrMV; and lane 3, preparation from healthy banana cv. Williams. B, Immunoblot: lane 1, purified BBrMV and lane 2, preparation from healthy banana cv. Williams. tions between AbaMV and BBrMV antibodies are probably not due to the absence of potyvirus virions.

RT-PCR. Using U341/D341 primers in RT-PCR, the expected amplification product of approximately $340 \mathrm{bp}$ was obtained from all $17 \mathrm{BBrMV}$-infected bananas and six AbaMV-infected bananas and abaca tested, but not from healthy bananas (Figs. 4 and 5).

Using the single-tube RT-PCR with "leaf soak" extract, a similar degree of amplification was obtained with reverse transcriptase concentrations of 20 to 200 units per tube. Lower, but detectable, levels were obtained with 5 units, and no product was detected with 0.5 units. The presence of RNasin in the RT-PCR mix resulted in a marginal increase in the quantity of PCR product. The greatest amount of specific cDNA was amplified with a 1:10 dilution of the "leaf soak" extract, but detectable product was obtained with up to a 1:1,600 dilution. BBrMV was still detectable in a "leaf soak" extract after storage at $-20^{\circ} \mathrm{C}$ for 34 days and two cycles of freeze-thawing.

Using the single-tube RT-PCR with "leaf soak" extract, specific cDNA was amplified from seven of eight BBrMV isolates tested and three of four AbaMV isolates tested. The isolates that were negative in this test were retested using TNAE as template, and specific cDNA amplified in both cases.

Southern blot hybridizations. The BBrMV-specific probe (p509-5) gave a positive reaction with all 17 BBrMV isolates tested under moderate stringency wash conditions and with all except BBrMV-513 under high stringency wash conditions (Fig. 5). No reaction was obtained with any of the six AbaMV isolates nor with any of the four healthy control samples. Conversely, the AbaMV-specific probe (p543-4) reacted under high stringency wash conditions with all six AbaMV isolates, but not with any of the BBrMV isolates or healthy controls (Fig. 5).

Cloning and sequencing. From a single cloning experiment with AbaMV-543, one virus-specific cloned insert of about $340 \mathrm{bp}$ was selected for probe generation.

From three separate cloning experiments, a total of 16 inserts of 341 bp derived from BBrMV-509 field-infected banana were sequenced. For 14 clones, the 92 amino acids translated from the coding sequence between the primer sites were identical to the consensus amino acid sequence of BBrMV (3). Two clones differed by a single amino acid substitution (Fig. 6).

\section{DISCUSSION}

The properties of BBrMV are consistent with other members of the genus Potyvirus. It is transmitted in the nonpersistent manner

TABLE 2. Plate-trapped antigen-enzyme-linked immunosorbent assay reactions between BBrMV a and AbaMV and antisera to various members of the family Potyviridae

\begin{tabular}{lccccc}
\hline & \multicolumn{4}{c}{ Virus isolates } \\
\cline { 2 - 3 } \cline { 5 - 6 } Antisera & 509 & 516 & & \multicolumn{2}{c}{ AbaMV } \\
\cline { 2 - 3 } \cline { 5 - 6 } BBrMV & $14,19^{\mathrm{b}}$ & $\mathrm{NT}^{\mathrm{c}}$ & & $2.6,2.9$ & $<2,2.4$ \\
DsMV & $\mathrm{NT}$ & $2.6,3.5$ & & 5.3 & $\mathrm{NT}$ \\
WSMV & $\mathrm{NT}$ & $3.1,3.7$ & & $\mathrm{NT}$ & $\mathrm{NT}$ \\
JGMV & 2 & $<2$ & & $<2$ & 2.4 \\
MDMV & 2.6 & $<2,<2$ & & 17 & 8.3 \\
SCMV & 3.5 & $<2,2.1$ & & $\mathrm{NT}$ & 11 \\
SrMV & 2.1 & $<2,2.2$ & & 5.5 & 4.3 \\
Agdia MAb & 6.3 & 3.7 & 11 & $\mathrm{NT}$ \\
\hline
\end{tabular}

a BBrMV = banana bract mosaic virus, AbaMV = abaca mosaic virus, DsMV $=$ dasheen mosaic virus, WSMV = wheat streak mosaic virus, JGMV = johnsongrass mosaic virus, MDMV = maize dwarf mosaic virus, $\mathrm{SCMV}=$ sugarcane mosaic virus, SrMV = sorghum mosaic virus, and Agdia $\mathrm{MAb}=$ Agdia potyvirus group monoclonal antibody (Agdia, Inc., Elkhart, IN).

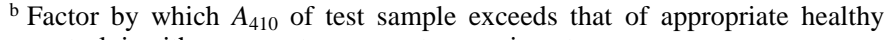
control, in either one or two separate experiments.

${ }^{\mathrm{c}} \mathrm{NT}=$ not tested. 
by several aphid species $(8,18,20)$, has flexuous, rod-shaped particles about $750 \times 11 \mathrm{~nm}(20)$, and has a coat protein that is related to other potyviruses at the serological and nucleotide sequence levels (3). The current work describes a virion purification method that has allowed antiserum production and physicochemical characterization. The properties reported here have also confirmed the classification of BBrMV as a potyvirus, i.e., presence of pinwheel inclusions in infected cells, virions with a length of about $725 \mathrm{~nm}$, serological cross-reaction in ELISA with other potyviruses, and the amplification of the expected product by RT-PCR with potyvirus degenerate primers. BBrMV from the Philippines appeared only distantly serologically related to AbaMV, DsMV, MDMV, SrMV, SCMV, and WSMV and was serologically unrelated to JGMV. Some, but not all, BBrMV isolates gave positive reactions with the Agdia potyvirus group monoclonal antibody (Agdia, Inc.). This result may reflect a low concentration of virions in the samples or, alternatively, epitope variation among isolates, a phenomenon observed with other potyviruses $(14 ; \mathrm{J}$. E. Thomas, unpublished data).

Three major protein bands from dissociated virions with sizes of 31,37 , and $39 \mathrm{kDa}$ were detected by SDS-PAGE. It is possible that these multiple bands are due to the presence of more than one virus. However, other known viruses of Musa were not detected by ELISA or nucleic acid hybridization in this sample, and only potyvirus-like particles were observed when purified extracts were

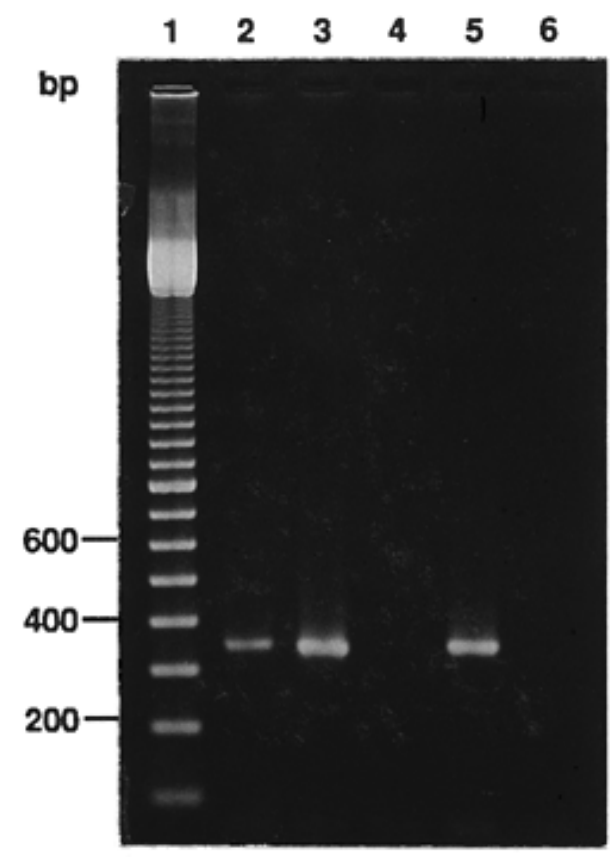

Fig. 4. Agarose gel electrophoresis of reverse transcription-polymerase chain reaction products derived from "leaf soak" extracts. Lane 1, 100-bp ladder; lane 2, banana cv. Cardaba infected with banana bract mosaic virus; lane 3, abaca infected with abaca mosaic virus; lane 4 , healthy banana cv. Williams; lane 5, maize cv. Jubilee infected with johnsongrass mosaic virus; and lane 6, healthy maize cv. Jubilee.

Fig. 5. A, Polymerase chain reaction (PCR) products amplified from total nucleic extracts of samples of banana bract mosaic virus (BBrMV) (lanes 218, and 36, including Kokkan disease isolate 513 in lane 16); abaca mosaic virus (AbaMV) (lanes 19, 31-35, and 37); healthy bananas (lanes 20-23 and 38-41); plasmid controls p509-5 (BBrMV, lanes 27 and 45) and p543-4 (AbaMV, lanes 28 and 46); PCR, cDNA, and extraction negative controls (lanes 24-26 and 42-44); and 100-bp ladder size markers (lanes 1, 29, 30, and 47), arrows indicate $340 \mathrm{bp}$ and $800 \mathrm{bp}$. B, Southern blot hybridization of the agarose gel from $\mathbf{A}$, reacted with a digoxigenin-labeled BBrMV-specific probe prepared from p509-5 and with chemiluminescent detection. C, Same as for $\mathbf{B}$, but using an AbaMV-specific probe prepared from p543-4. examined by electron microscopy. When cDNA from this sample was amplified by RT-PCR using degenerate potyvirus group primers and the products cloned and sequenced, all 16 inserts from three independent cloning experiments were identified as BBrMV. By analogy with other potyviruses, these three protein bands are probably forms of the coat protein of BBrMV, and the heterogeneity in size may have arisen from either differential cleavage of
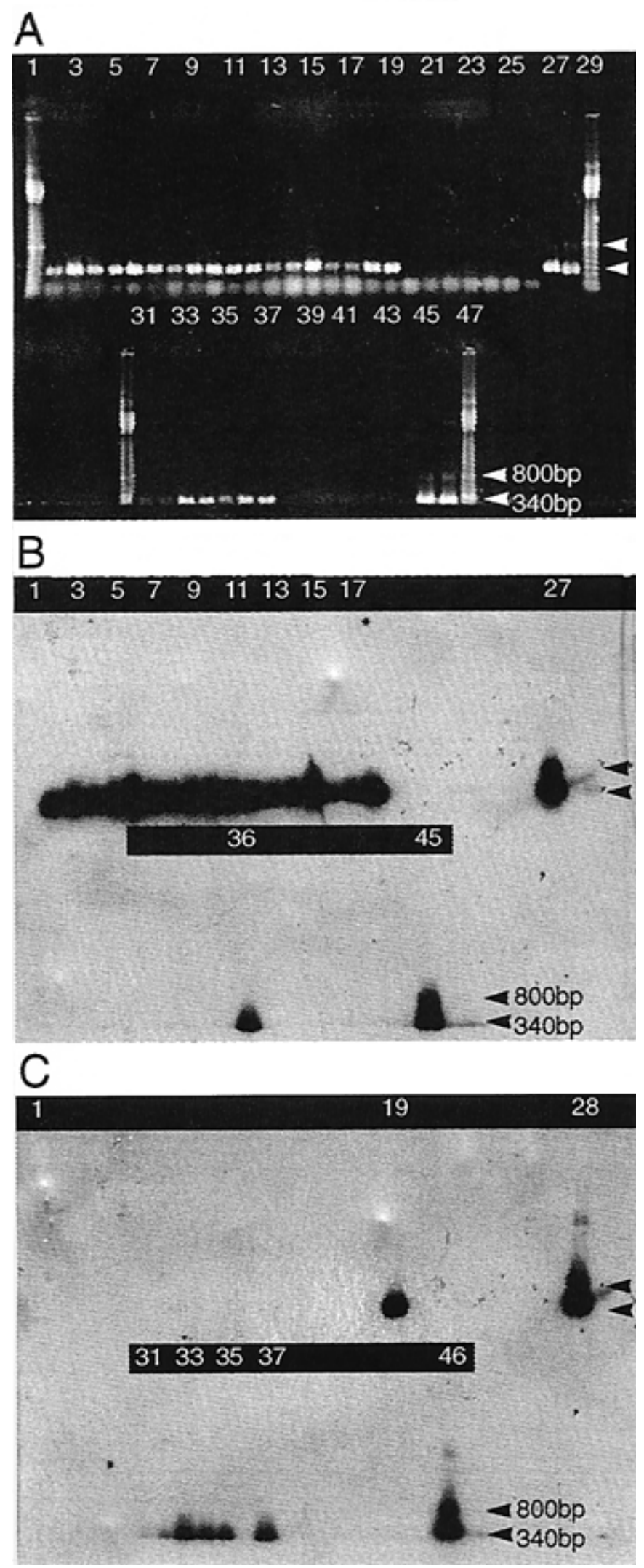


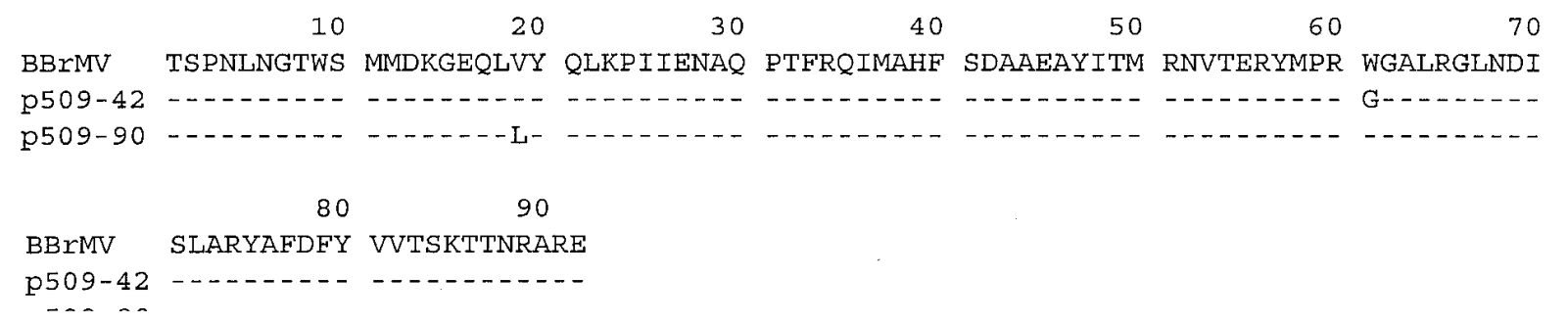

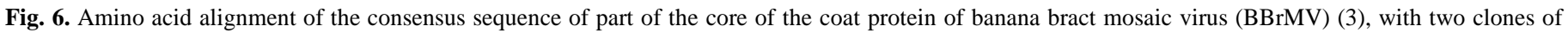
BBrMV-509 having amino acid substitutions. Fourteen additional clones of BBrMV-509 were identical to the consensus amino acid sequence.

the polypeptide precursor of the coat protein or from degradation of the coat protein during and after virion purification (25). The latter possibility appears more likely, as Bateson and Dale (3) reported a single major protein of $38 \mathrm{kDa}$ in partially purified preparations of BBrMV.

BBrMV has not been transmitted by any means to hosts outside the genus Musa nor to any host by mechanical inoculation $(8,20)$, making the biological purity of isolates difficult to establish and hampering fulfillment of Koch's postulates. Nevertheless, we have provided strong evidence that BBrMV is, in fact, the causal agent of banana bract mosaic disease. BBrMV-509 was obtained from a single field plant. The sample was extensively tested for the presence of other viruses, especially potyviruses, but found to contain BBrMV only. All 16 virus-specific clones obtained from this isolate were identified as BBrMV. BBrMV was consistently associated with the presence of typical disease symptoms in samples from three countries. A cDNA probe prepared from BBrMV509 reacted specifically with 17 such samples, but not with any of six samples infected with AbaMV. Additionally, a polyclonal antiserum prepared to this isolate reacted strongly with all 24 samples of banana bract mosaic diseased tissue examined in this work, very weakly with AbaMV, and not with samples infected with BBTV, BSV, or CMV.

Symptoms in banana similar to those caused by BBrMV have been noted in India $(1,2)$, where it is locally known as Kokkan disease. Using ELISA, we have shown that bananas with this disease and also banana samples from Sri Lanka were infected with BBrMV. The reaction of an Indian Kokkan disease sample (BBrMV-513) with a BBrMV-509 probe with moderate, but not high, stringency washing is consistent with the observation that they differ by about $13 \%$ in nucleotide sequence in this portion of the coat protein gene (C. F. Gambley, A. D. W. Geering, and J. E. Thomas, unpublished data).

The detection of BBrMV in field-infected and glasshouse-inoculated banana was achieved by both ELISA and RT-PCR. The minimum concentration of BBrMV detectable by DAS-ELISA was $16 \mathrm{ng} / \mathrm{ml}$, comparable with many other potyvirus ELISA systems, and the assay should prove suitable for routine field screening. The RT-PCR using the degenerate primers U341/D341 has potential as a general potyvirus test for bananas, as a number of isolates of both BBrMV and AbaMV were amplified. The singletube RT-PCR using the "leaf soak" method was convenient, though not wholly reliable, as one BBrMV isolate and one AbaMV isolate were not detected, even though they tested positive using TNAE as template in RT-PCR. Of all techniques used, the smallest tissue samples were in the "leaf soak" extracts, and sampling errors could allow infection to be missed if the virus is unevenly distributed. Also, the relative sensitivity of RT-PCR with "leaf-soak" extract is probably less than that with TNAE, because of less efficient extraction of virions and possible presence of inhibitors to PCR.

Despite the apparent similarities in symptoms caused by AbaMV and BBrMV in bananas $(18,26)$, the results presented in this work suggest that the two viruses are distinct. Six suspected AbaMV samples gave positive reactions with an AbaMV-specific cDNA probe, but failed to react with a BBrMV-specific cDNA probe and reacted weakly with BBrMV-specific antibodies in ELISA. By contrast, one suspected AbaMV sample (BBrMV510 ), originally collected from abaca, did react strongly with the BBrMV-specific probe and antibodies, but not the AbaMV-specific probe, and, thus, may originally have been misidentified. In PTA-ELISA, suspected AbaMV samples reacted relatively more strongly with all antibodies to viruses of the SCMV subgroup tested and more weakly with antibodies to BBrMV than did control BBrMV samples. These results support previous work (9) based on transmission of AbaMV to maize (Zea mays) and a reaction between SCMV and antiserum to AbaMV in microprecipitin tests, which suggests that AbaMV may be a member of the SCMV subgroup of potyviruses. Sequencing of the 3'-untranslated region and the coat protein gene of AbaMV is currently underway to clarify this hypothesis.

It appears that AbaMV and BBrMV are distinct potyviruses, but can each infect banana and abaca and, thus, the identification of viruses in both these crops and the indexing of Musa germ plasm $(1,2)$ must take both these viruses into account.

\section{ACKNOWLEDGMENTS}

This work was supported by the International Network for the Improvement of Banana and Plantain, the United Nations Development Program, the Horticultural Research and Development Corporation, and the Banana Industry Protection Board. We thank N. Bajet, L. Kenyon, L. V. Magnaye, and D. M. Persley for supplying virus-infected banana from the Philippines; K. Jagadish Chandra for supplying a sample of Kokkan disease from India; D. R. Jones for supplying samples from India and Sri Lanka; V. Steele for technical assistance; and R. G. Dietzgen for helpful discussions.

\section{LITERATURE CITED}

1. Anonymous. 1992. Bananas, Plantains and INIBAP. Annual Report 1992. International Network for the Improvement of Banana and Plantain, Montpellier, France.

2. Anonymous. 1993. Bananas, Plantains and INIBAP. Annual Report 1993. International Network for the Improvement of Banana and Plantain, Montpellier, France.

3. Bateson, M. F., and Dale, J. L. 1995. Banana bract mosaic virus: Characterisation using potyvirus specific degenerate primers. Arch. Virol. 140: 515-527.

4. Burns, T. M., Harding, R. M., and Dale, J. L. 1994. Evidence that banana bunchy top virus has a multiple component genome. Arch. Virol. 137: 371-380.

5. Clark, M. F., and Adams, A. N. 1977. Characteristics of the microplate method of enzyme-linked immunosorbent assay for the detection of plant viruses. J. Gen. Virol. 34:475-483.

6. Dekker, E. L., Derks, A. F. L. M., Asjes, C. J., Lemmers, M. E. C., Bol, J. F., and Langeveld, S. A. 1993. Characterization of potyviruses from tulip and lily which cause flower-breaking. J. Gen. Virol. 74:881-887.

7. Devereux, J., Haeberli, P., and Smithies, O. 1984. A comprehensive set of sequence analysis programs for the VAX. Nucleic Acids Res. 12:387-395.

8. Diekmann, M., and Putter, C. A. J. 1996. FAO/IPGRI Technical Guidelines for the Safe Movement of Germplasm. No. 15. Musa. 2nd ed. Food and Agriculture Organization of the United Nations, Rome, and International Plant Genetic Resources Institute, Rome.

9. Eloja, A. L., and Tinsley, T. W. 1963. Abaca mosaic virus and its relationship to sugarcane mosaic. Ann. Appl. Biol. 51:253-258.

10. Greber, R. S., and Gowanlock, D. H. 1979. Cereal chlorotic mottle vi- 
rus-Purification, serology and electron microscopy in plant and insect tissues. Aust. J. Biol. Sci. 32:399-408.

11. Hammond, J., and Lawson, R. H. 1988. An improved purification procedure for preparing potyviruses and cytoplasmic inclusions from the same tissue. J. Virol. Methods 20:203-217.

12. Hull, R. 1993. Nucleic acid hybridization procedures. Pages 253-271 in: Diagnosis of Plant Virus Diseases. R. E. F. Matthews, ed. CRC Press, Inc., Boca Raton, FL.

13. Hull, R., Milne, R. G., and van Regenmortel, M. H. V. 1991. A list of proposed standard acronyms for plant viruses and viroids. Arch. Virol. 120:151-164.

14. Jordan, R. 1992. Potyviruses, monoclonal antibodies, and antigenic sites. Pages 81-95 in: Potyvirus Taxonomy (Arch. Virol. Suppl. 5). O. W. Barnett, ed. Springer-Verlag, Vienna.

15. Laemmli, U. K. 1970. Cleavage of structural proteins during the assembly of the head of bacteriophage T4. Nature 227:680-685.

16. Langeveld, S. A., Dore, J.-M., Memelink, J., Derks, A. F. L. M., van der Vlugt, C. I. M., Asjes, C. J., and Bol, J. F. 1991. Identification of potyviruses using the polymerase chain reaction with degenerate primers. J. Gen. Virol. 72:1531-1541.

17. Lockhart, B. E. L. 1986. Purification and serology of a bacilliform virus associated with banana streak disease. Phytopathology 76:995-999.

18. Magnaye, L. V., and Espino, R. R. C. 1990. Note: Banana bract mosaic, a new disease of banana. I. Symptomatology. Philipp. Agric. 73:55-59.

19. Mowat, W. P., and Dawson, S. 1987. Detection and identification of plant viruses by ELISA using crude sap extracts and unfractionated antisera. J. Virol. Methods 15:233-247.

20. Muñez, A. R. 1992. Symptomatology, transmission, and purification of banana bract mosaic virus (BBrMV) in "Giant Cavendish" banana. M.Sc. thesis. University of the Philippines, Los Baños.

21. Pearson, M. N., Thomas, J., and Randles, J. W. 1994. Detection of an unidentified potyvirus from Roystonea regia palm using the polymerase chain reaction and degenerate, potyvirus specific, primers and potential problems arising from the amplification of host plant DNA sequences. J. Virol. Methods 50:211-218.

22. Purcifull, D. E. 1966. Some properties of tobacco etch virus and its alkaline degradation products. Virology 29:8-14.

23. Roperos, N. I., and Magnaye, L. V. 1991. Status of banana diseases in the Philippines. Pages 52-66 in: Banana Diseases in Asia and the Pacific. R. V. Valmayor, B. E. Umali, and C. P. Bejosano, eds. International Network for the Improvement of Banana and Plantain, Montpellier, France.

24. Sambrook, J., Fritsch, E. F., and Maniatis, T. 1989. Molecular Cloning: A Laboratory Manual. Cold Spring Harbor Laboratory Press, Cold Spring Harbor, NY.

25. Shukla, D. D., Ward, C. W., and Brunt, A. A. 1994. The Potyviridae. CAB International, Cambridge.

26. Stover, R. H. 1972. Banana, Plantain and Abaca Diseases. Commonwealth Mycological Institute, Kew, Surrey, England.

27. Thomas, J. E., and Dietzgen, R. G. 1991. Purification, characterization and serological detection of virus-like particles associated with banana bunchy top disease in Australia. J. Gen. Virol. 72:217-224.

28. Thompson, J. D., Higgins, D. G., and Gibson, T. J. 1994. CLUSTAL W: Improving the sensitivity of progressive multiple sequence alignment through sequence weighting, position specific gap penalties and weight matrix choice. Nucleic Acids Res. 22:4673-4680.

29. Thomson, D., and Dietzgen, R. G. 1995. Detection of DNA and RNA plant viruses by PCR and RT-PCR using a rapid virus release protocol without tissue homogenisation. J. Virol. Methods 54:85-95.

30. Wang, D., Hayes, I. M., and Maule, A. J. 1992. Procedures for the efficient purification of pea seed-borne mosaic virus and its genomic RNA. J. Virol. Methods 36:223-230.

31. Zaitlan, M., and Israel, H. W. 1975. Tobacco mosaic virus. CMI/AAB Descriptions of Plant Viruses (151). Commonwealth Mycological Institute, Kew, Surrey, England, and Association of Applied Biologists, Wellesbourne, Warwick, England. 